$$
\begin{gathered}
\text { スキューバダイビングの耳鼻科的トラブル } \\
\text { ーァンケート調査成績よりー }
\end{gathered}
$$

佐伯 忠彦・小林 丈二・上甲 英生

\title{
Otorhinolaryngological Disorders Related to Scuba Diving
}

\author{
Tadahiko Saiki, Jyoji Kobayashi and Hideo Jyoko \\ (Uwajima City Hospital)
}

\begin{abstract}
Otorhinolaryngological disorders through a questionnaire were investigated in 163 scuba divers (99 males and 64 females) over the period August, 1994 to December, 1995. Seventy-four cases (45.4\%) of the 163 had dived excessively as indicated by poor Eustachian tube function. Moreover, 14 cases $(8.7 \%)$ of 161 had taken medication to perform Valsalva's method more easily. During underwater navigation, earache, hearing loss, tinnitus, vertigo (or dizziness) and sinus squeeze were reported in 95 cases $(63.3 \%)$ of 150,10 cases $(6.7 \%)$ of 150,13 cases $(8.8 \%)$ of 147,17 cases $(11.4 \%)$ of 149 and 25 cases (16.4\%) of 152, respectively. In surface navigation, the incidence of the same problems was 21 cases $(14.7 \%)$ of 143,5 cases $(3.3 \%)$ of 150,12 cases $(8.1 \%)$ of 149,21 cases $(14.7 \%)$ of 143 and 11 cases $(7.3 \%)$ of 150 , respectively. Alternobaric facial palsy occurred in 6 cases (4.1\%) of 148 after diving. Thirty-three cases (20.5\%) of 161 visited the hospital because of otorhinolaryngological disorders related to scuba diving. The incidence of problems in divers who dived excessively and the number of hospital visits among those who dived excessively, were higher than those among other divers. In conclusion, divers should be advised to stop diving during conditions of tubal dysfunction owing to the common cold and so on.
\end{abstract}

Key words : otorhinolaryngological disorder, scuba diving, questionnaire, tubal dysfunction

はじめに

近年，スキューバダイビング人口の増加に伴い，ダイ ビングによる合併症が注目されている1) 4). 当院の所在 する宇和島市近海は水質が良好なことから，地元住民の みならず遠隔地からもダイビングを目的に訪れる人が多 く，これに伴い最近ではダイビング後の耳鼻科的トラブ ルで当科を受診する患者が増加している．このような背 景から今回，ダイビングにおける耳鼻科的トラブルの実 態を把握する目的で，ダイバーにアンケート調査を行っ たので，その結果につき若干の考察を加えて報告する.

\section{対 象}

対象は平成 6 年 8 月から平成 7 年 12 月末むでの間に宇 和島市およびその近郊のダイビングショップをボンベの 借用のために利用したスキューバダイバーのらち, 筆記 によるアンケート調査に協力が得られた163名である. 性別は男性が99名, 女性が64名であり, 年代別には20歳 代が81名と最も多かった(図 1). 職種では回答のあった 144名中, スポーツダイバーが127名 (88.2\%) (以下, 127 名/144名 $(88.2 \%)$ のごとく, 対象数/回答総数(パーセン ト)で表記する.)で, プロダイバーが17名(11.8\%)であ った.

ダイビング歴は 1 年以下が 61 名/155名 (39.4\%) と最も 


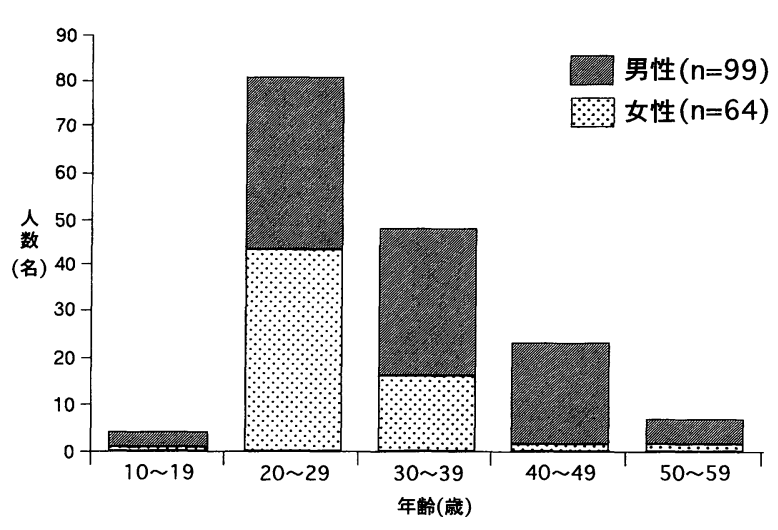

図1 対 象

多く平均は 4.5 年であった. ダイビング回数は 30 回未満 が78名/154名(50.6\%)を占めていた。 な抽，平均ダイビ ング深度は $5 \mathrm{~m} \sim 35 \mathrm{~m}$ の範囲であり，その平均は 17.2 mであった。

\section{結果}

\section{1 ) 耳鼻科疾患の既往歷}

ダイビングライセンスを取得する前に耳鼻科的疾患の 既往があった人は52名/156名(33.3\%)であった．疾患と しては中耳炎が30名と最も多く，以下アレルギー性鼻炎 が15名, 外耳炎が10名, 慢性副鼻腔炎が 4 名などの順で あった(図 2).

2 ) 耳抜きについて

ダイビングを始める前に耳抜き，すなわちバルサルバ 法を知っていたかの問いに対して，はいと答えた人は 108名/162名(66.7\%)であった。耳抜きの難易について は，容易にできる人が87名/162名(53.7\%)，時々できに くい人が 63 名 $(38.9 \%)$ ，しばしばできにくい人が 12 名

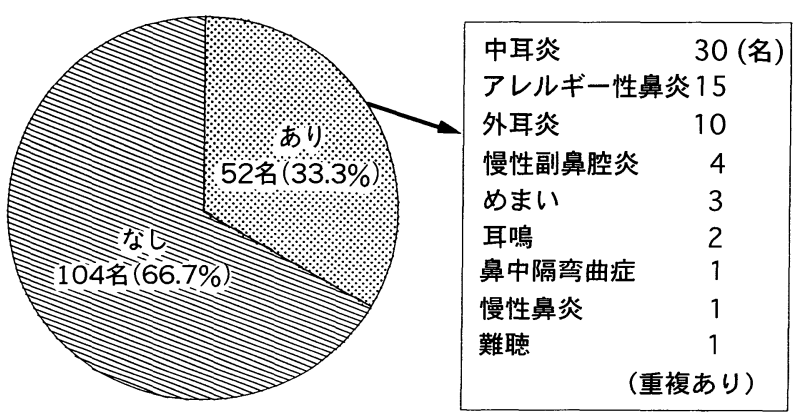

図 2 耳鼻科疾患の既往歴
(7.4\%)であり, 約半数の人は耳抜きに支障をきたした 経験があった。

何 $\mathrm{m}$ 位潜った時に耳抜きが必要になるかについては 3 $\mathrm{m}$ と答えた人が 55 名/155名 $(35.5 \%)$ で最も多く, 全体 では $3 \mathrm{~m}$ 以下が 100 名 $(64.5 \%)$ を占め平均は $3.4 \mathrm{~m}$ であ った(図 3 )。

風邪気味や耳抜きができにくいときにも潜ったことが あるかの問いでは，74名/163名(45.4\%)が無理をして潜 った経験があった．耳の痛みや耳抜きができずにダイビ ングを中止せざるを得なかった人は24名/159名(15.1\%) いた.

ダイビング前に耳抜きを良くするために薬を使用した ことがあるかについては，はいと答光た人が14名/161名 (8.7\%)あり, その内訳は抗アレルギー剤が 5 名, 点鼻 薬が 3 名, 抗生物質が 2 名, 不明が 4 名であった.

3 ) ダイビングに伴う耳鼻科的トラブルについて

ダイビング中に耳の痛みを感じたことがあるかの問い に対しては，潜る時に95名/150名(63.3\%)，浮上する時 に21名/143名(14.7\%)に訴えがあった．難聴を感じた人 は潜る時に10名/150名(6.7\%)，浮上する時に 5 名/150 名 (3.3\%)であった．耳鳴を感じた人は潜る時に13名/ 147名 (8.8\%), 浮上する時に12名/149名 (8.1\%)であり, めまいについては潜る時に17名/149名(11.4\%)に，浮上 する時に21名/143名(14.7\%)に各々訴光があった。なお， めまいの種類は, 潜る時に回転性が11名, 浮動性が 6 名 であり，浮上寸る時に回転性が11名，浮動性が10名であ った．ダイビング中に額や頓に痛みを感じた人は潜る時 に25名/152名(16.4\%)，浮上する時に11名/150名(7.3

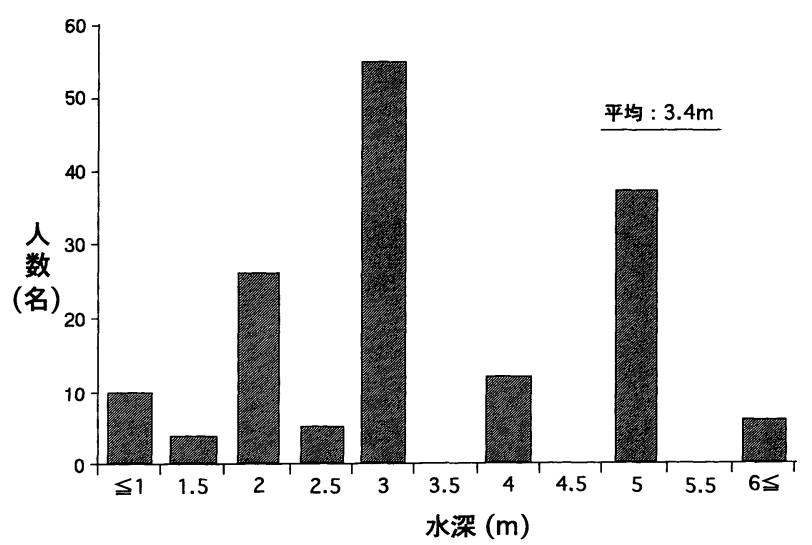

図 3 耳抜きが必要になる水深 
\%)であった. ダイビング後の顔面神経麻痺は 6 名 $/ 148$ 名(4.1\%)にみられた.

無理にダイビングをした経験のある人 $(\mathrm{n}=74)$ とそう でない人 $(n=88)$ にわけて耳鼻科的トラブルの発生状況 を検討してみると，潜る時の耳痛を除く少なくとも 1 つ 以上の耳鼻科的症状を自覚した人は，前者が 39 名 $/ 74$ 名 (52.7\%), 後者が23名/88名(26.1\%)であり，無理にダ イビングをした経験のある人に耳鼻科的トラブルの発生 が多かった。

4 ）ダイビング後の耳鼻科受診について

ダイビング後に耳鼻科を受診したことがあるかの問い

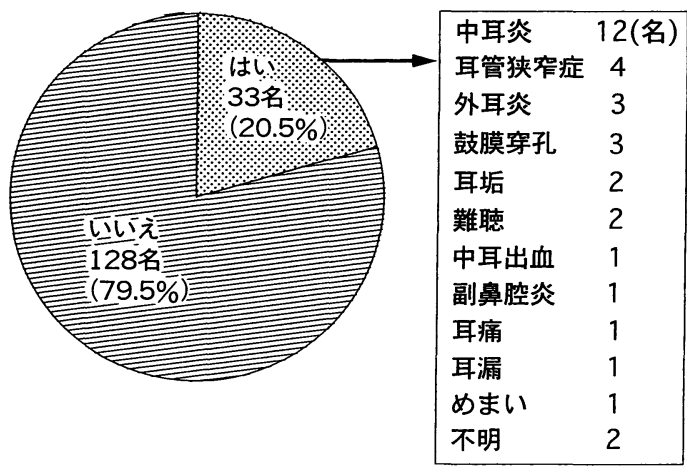

図 4 ダイビング後の耳鼻科受診状況
に対しては，はいと答えた人は33名/161名 (20.5\%)であ り, その内訳は中耳炎が12名と最も多く, 以下, 耳管狭 窄症が 4 名, 外耳炎が 3 名などの順で，耳に関する疾患 が多くを占めていた(図4)。なお，病名はダイバーが記 載した病名をそのまま用いた。

耳鼻科を受診した人 $(\mathrm{n}=33)$ と，耳鼻科を受診しなか った人 $(\mathrm{n}=128)$ に分けて耳抜きの難易を比較すると, 容易にできる人は前者で 8 名/33名 $(24.2 \%)$, 後者で78 名/128名 $(60.9 \%)$ と，耳鼻科を受診した人の方に耳抜き の不良な割合が高かった(図 5-a)。また，風邪などで体 調が悪い時にも無理にダイビングをした経験は前者が 28 名/33名 (84.8\%), 後者が46名/128名(35.9\%) と, 耳鼻 科を受診した人の方に無理にダイビングをした経験者の 割合が高かった(図 5-b).

\section{考察}

近年, スキューバダイビングの流行に伴いダイビング による種々のトラブルが報告されている1) 7)。特に, 耳 鼻咽喉科領域では圧変化の影響を受けやすい中耳や副鼻 腔を取り扱らため，我々がダイビングによる障害患者に 接する機会は多い。しかし，これまでに耳鼻咽喉科を受 診した症例についての報告2)5 〜7) は散見されるものの， ダイバー側からみた耳鼻科的トラブルについての実態調

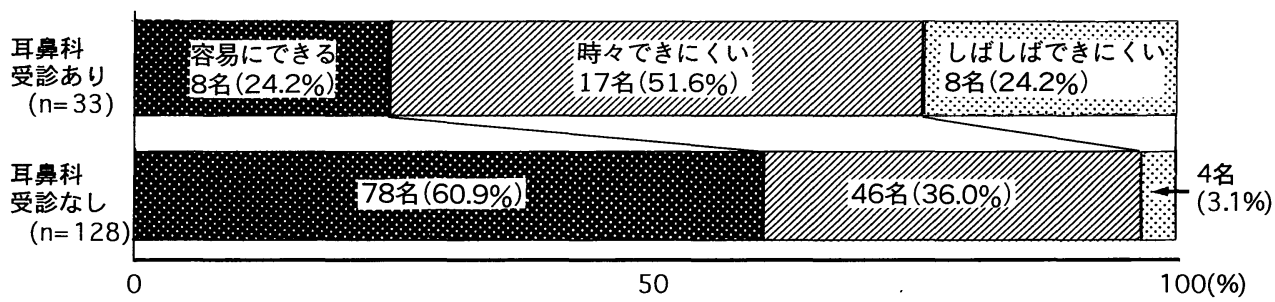

( a )

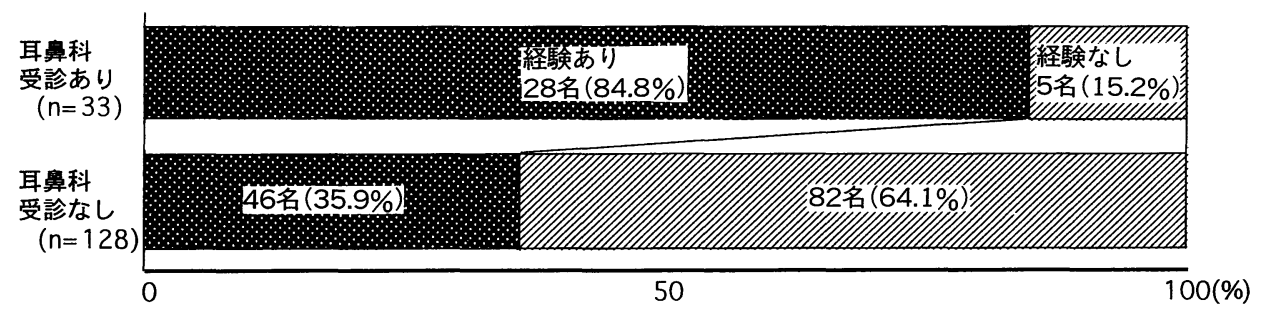

(b)

図 5-a 耳鼻科受診の有無からみた耳抜きの難易度

-b 耳鼻科受診の有無からみた無理なダイビングの経験者の割合 
查を行った報告は少ない(4)899). 今回の検討からは，重篤 な症例はみられなかったものの実際には予想以上に圧障 害によると思われる耳鼻科的トラブルが発生しているこ とが分かった.

今回検討した耳鼻科的トラブルのらち，潜る時に耳痛 を訴える人が多いのは，水圧で耳痛を感じるまで耳抜き をしないためと思われる．どの位の水深で耳抜きが必要 となるかについては $3 \mathrm{~m}$ 以下が $64.5 \%$ と多くを占め, 平均は $3.4 \mathrm{~m}$ であった。この数值は理論的に耳管機能 不全状態で鼓膜に穿孔が起こりらる水深 $(1.3 \sim 5.3 \mathrm{~m})$ の範囲1に含をれる．この水深を越えてもさらに耳抜き をせず潜ると中耳腔内の粘膜や血管が破綻し, やがて鼓 膜穿孔や外リンパ瘦を起こすことになる.大久保10) は $1 \mathrm{~m}$ 前後で耳抜きを行う必要があり, $3 \mathrm{~m}$ 近くまでには 1 2 回の耳抜きをすべきで，耳が痛くなる前の早めの耳抜 きを勧めている.

通常, 耳鼻科的トラブルによる症状の発生は潜る時が 浮上する時よりも頻度が高くなることが多いが，めまい に関しては浮上する時にトラブルが多くなるよらであ る11). めまいの種類にはダイビング中に外耳道に入る 冷水の左右耳の不均等な反応によるめまい (caloric stimulation vertigo) と浮上する時に一側中耳における圧 上昇により前庭器官を刺激することによるめまい (alternobaric vertigo)がある ${ }^{12)}$. 両者の区別は難しいが，少 なくとも浮上する時に生じるめまいは後者といわれてい る13). 浮上する時にめまいが起こりやすい理由として柳 田ら ${ }^{11)}$ はめまいは外耳道圧に比べて中耳厈が相対的に 陽压になった時に主として起こるためと考えている。一 般に気圧外傷は相対的圧变化が中耳腔＜外気圧の時に鼓 膜穿孔などの耳障害は多く, 障害の程度は中耳腔 $>$ 外耳 圧のスクイーズ状態が形成される時が重症であるとされ ている2).一方, 副鼻腔の気圧外傷は洞内が相対的に低 圧となる潜る時に発生しやすい:14). 前頭洞, 次いで篩骨 洞の障害が多く, 症状としては前頭部や鼻根部の激痛や 鼻出血がみられる3).今回の検討に扣ける各症状は潜る 時の耳痛以外は $3.3 \%$ 16.4\%の頻度であった. なお， まれとされるダイビング後の顔面神経麻痺も 6 名 (4.1 \%)にみられたことは興味深い, 込田ら゙)はダイビング に伴ら顔面神経麻痺は顔面神経管の水平部の間隙が存在 する場合に圧力がかかり一過性に起こるものが多く, 通 常は数分から数時間のうちに改善すると報告している. 今回の 6 例も発症後耳鼻科を受診していないため予後は
良好であったものと思われる．

今回の検討では潜る時の耳痛を除く少なくとも 1 つ以 上の耳鼻科的症状を自覚した人の合計が 162 名中 62 名之 約 4 割を占めたが，そのらち無理に潜った経験のある人 にトラブルの発生は多かった。また，耳鼻科を受診した 人としなかった人とに分けて検討してみても前者に耳抜 きが容易でなかったり，無理にダイビングをした人の割 合が高かった. このことは, ダイビングに際して, 耳抜 きが大変重要であり，耳抜きができにくい状態では無理 をしてダイビングをすべきでないことを示唆するものと いえる.

ダイビング前に薬を使用した経験者が14名/161名 (8.7 \%)みられたが，その目的は主にアレルギー性鼻炎など による鼻症状の改善を図り耳抜きを良くするためであっ た. 大久保 ${ }^{10)}$ は抗ヒスタミン剂を耳管の浮腫性変化を 回避する目的で服用することもあるが，薬剤に頼るより も普段の健康に留意し上気道感染などに十分注意するこ とが肝要と述べている，さらに，連続してダイビングを すると耳管開放圧は高くなるため，2，3 日目の無理な ダイビングは要注意ともいわれている15)。実際, スポー ツダイバーの多くは遠隔地からダイビングスポットまで 来て括り，睡眠不足や疲労があっても短期間に無理をし てダイビングをしているのが実情である.

以上，スキューバダイバ一側からみた耳鼻科的トラブ ルについて検討したが，スキューバダイビングは無理な 計画をたてずダイビングの基本を守れば，決して危険な マリンスポーツではないといえる。従って，我々耳鼻科 医は外来にダイビング後の耳鼻科的トラブルで患者が受 診した場合, 病変が完治するまでダイビングを中止させ るとともに, 今後, 感冒や疲労などで体調が悪い時や耳 抜きが容易にできない時には無理にダイビングをしない ように指導すべきと思われる。

\section{まとめ}

1) スキューバダイビングに括けるダイバー側からみ た耳鼻科的トラブルについてアンケート調査を行った。

2 ) 対象は平成 6 年 8 月から平成 7 年12月末をでに筆 記によるアンケート調査に協力が得られたスキューバダ イバー163名であった。性別は男性99名, 女性64名であ り，年代別には20歳代が 81 名と最も多かった.

3 ）耳抜きができにくい状態でも $45.4 \%$ は無理に潜っ た経験があった。 
4 ）ダイビング前に耳抜きを良くするために薬を使用

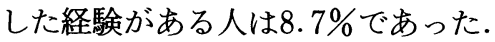

5 ）耳痛を感じた人は潜る時に $63.3 \%$ ，浮上する時に $14.7 \%$ であり, 難聴は各々 $6.7 \%, 3.3 \%$ でった.

6) 耳鳴は潜る時に $8.8 \%$, 浮上する時に $8.1 \%$ であり, めまいは各々 $11.4 \%, 14.7 \%$ であった。

7 ）額や頓に痛みを感じた人は潜る時に $16.4 \%$, 浮上 する時に $7.3 \%$ であり，ダイビング後に顔面神経麻痺に

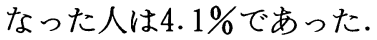

8 ）ダイビング後に耳鼻科を受診した人は $20.5 \%$ であ り, 中耳炎, 耳管狭窄症, 外耳炎などの順に多かった。

9 ）感冒や疲労などで体調が悪い時や耳抜きが容易で ない時には, 無理にダイビングをしないように指導すべ きと思われた。

稿を終えるに臨み,ご校閲を頂きました愛媛大学医学部耳鼻 咽喉科学教室暁 清文助教授に深謝致します。また，アンケー 卜調査にご協力頂きました富平哲生氏, 富岡桂一氏, 宮川 修 氏に厚く御礼申し上げます。

な拉, 本論文の要旨は第27回日耳鼻愛媛県地方部会 (1995. 松山), および第58回耳鼻咽搌科臨床学会(1996. 名古屋)にお いてロ演した。

\section{参考文献}

1) Famer JC : Diving injuries to the inner ear. Ann Otol Suppl $36: 1 \sim 20,1977$.

2) 大久保化, 渡辺 勈, 小山澄子, 他: 成人の耳管機能と耳

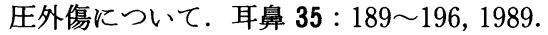

3 ）柳田則之 : 気压外傷. JOHNS 5 ：459 464, 1989.
4) 大平泰行, 矢部多加夫, 加我君孝, 他: 職業潜水夫と耳科

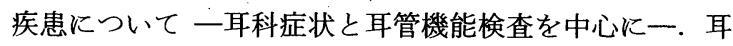
喉頭頸 $63: 13 \sim 17,1991$.

5 ）込田茂夫, 伊藤享子, 今井昭雄, 他 : 寸もぐりによる barotrauma 94 例. 耳喉 $56: 273 \sim 278,1984$.

6 ）込田茂夫, 北条和博, 中野雄一：すもぐりによる alternobaric facial paralysis $の 1$ 例. 耳喉 $57: 691 \sim 695,1985$.

7 ）小出奈々, 五十嵐文雄, 佐藤 充, 他: スキューバダイビ ングによる卵円空破裂の 1 症例。日耳鼻 $90 ： 1291 \sim 1292$, 1987.

8 ) 知念信雄, 楠見 彰, 江洲浩明, 他 : ダイビングに伴う耳

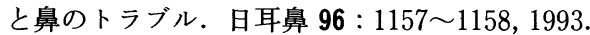

9 ）植松美紀子，梅田悦生：ダイバーズ外来の必要性について

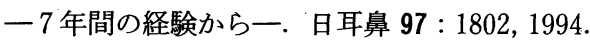

10）大久保僣水と耳鼻咽喉科疾患. 臨床スポーツ医学 11 : 1011 1018, 1994.

11）柳田則之, 中島 務, 植田広海, 他 : 耳気圧外傷の臨床. 耳鼻臨床 $88: 1243 \sim 1252,1995$.

12）柳田則之：高気圧環境負荷と気圧外傷. 耳気圧外傷の基礎 とその臨床. 51 98頁, 名鉄局印刷, 名古屋, 1994.

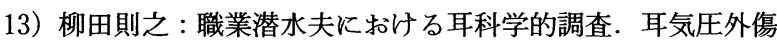
の基礎とその臨床．152 158頁, 名鉄局印刷, 名古屋, 1994.

14) Fagan $P$, Mckenzie $B$ and Edmonds $C$ : Sinus barotrauma in divers. Ann Otol $85: 61 \sim 64,1976$.

15）大久保化 : 気圧外傷の診断と治療 一ダイビングの耳厈外 傷について一. 頭頸部外科 $3: 3 \sim 9,1993$.

$$
\left.\begin{array}{l}
\text { 原稿受付 : 平成 } 8 \text { 年 } 2 \text { 月 } 13 \text { 日 } \\
\text { 原稿採択 : 平成 } 8 \text { 年 } 3 \text { 月 } 13 \text { 日 } \\
\text { 別刷請求先 : 佐伯忠彦 } \\
\text { 干798 宇和島市御殿町 } 1-1 \\
\text { 市立宇和島病院耳鼻咽喉科 }
\end{array}\right)
$$

